\title{
Evidence for Oxidative Stress Involved in Physiological Leaf Spot Formation in Winter and Spring Barley
}

\author{
Yue-Xuan Wu and Andreas von Tiedemann
}

Department of Phytomedicine, Faculty of Agriculture, University of Rostock, Satower Strasse 48, 18051 Rostock, Germany. Current address of A. von Tiedemann: Institute of Plant Pathology and Plant Protection, University of Göttingen, Grisebachstrasse 6, 37077 Göttingen, Germany. Accepted for publication 19 October 2001.

\begin{abstract}
Wu, Y. X., and von Tiedemann, A. 2002. Evidence for oxidative stress involved in physiological leaf spot formation in winter and spring barley. Phytopathology 92:145-155.

A leaf spot disease with unknown etiology has become more pronounced in spring and winter barley in Germany in recent years. The symptoms are similar to net blotch and Ramularia leaf spots, but the causal agents of these diseases are not identified. The symptom expression varied much on cultivars. Cultivars most affected by the disease of both spring and winter barley showed a significantly higher level of superoxide $\left(\mathrm{O}_{2}^{-}\right)$production and lipid peroxidation (malondialdehyde), but a lower level of antioxidant potential expressed as superoxide dismutase (SOD) activity, catalase activity, and integral water-soluble

ear emergence and milk ripeness was established in the most sensitive winter barley cv. Anoa $\left(r^{2}=0.9622\right)$ and spring barley cv. Barke $\left(r^{2}=\right.$ 0.9434). Leaf $\mathrm{H}_{2} \mathrm{O}_{2}$ levels increased with the severity of leaf spots. The histochemical localization of $\mathrm{O}_{2}^{-}$and $\mathrm{H}_{2} \mathrm{O}_{2}$ in the tissues adjacent to leaf spots indicated that these two active oxygen species (AOS) are involved in the formation of leaf spots. Reduction of symptom severity by applying strobilurin and azole fungicides was always associated with elevated SOD activity and ACW content and suppressed $\mathrm{O}_{2}^{-}$production. However, peroxidase activities were significantly higher in sensitive cultivars and in more severely affected tissues and decreased by applying fungicides. Thus, it is assumed that a possible genetic mechanism based on the imbalanced AOS metabolism contributes to formation of physiological leaf spots.
\end{abstract} antioxidant capacity (ACW) than insensitive cultivars. A high positive correlation between $\mathrm{O}_{2}^{-}$production and leaf spot development between
Additional keywords: antioxidant enzymes, nonparasitic leaf necrosis.
A leaf spot disease with unknown etiology has occurred in spring and winter barley in Germany since the 1980s, and has become more pronounced in recent years. The disease severity may achieve levels of 30 to $60 \%$ coverage on the uppermost three leaves in sensitive cultivars, with yield loss estimates ranging from 10 to $20 \%$ (29). Similar symptoms have been found on barley and wheat in the Pacific Northwest and San Luis Valley in the United States (6), western Canada (15), the U.K. (N. Havis, personal communication), Switzerland, and Australia (J. S. Moroni, personal communication).

Several terms have been formed for this symptom such as physiological leaf spots (PLS), nonparasitic necrosis, genetic necrosis, tar spots, and resistance necrosis. The occurrence of these leaf spots varies much with cultivars, regions, and weather conditions. Azole and strobilurin fungicides strongly reduce the symptoms $(31,47)$.

PLS in spring and winter barley may be confused with net blotch (Drechslera teres), spot blotch (Bipolaris sorokiniana), scald (Rhynchosporium secalis), mlo-necroses, Ascochyta leaf spots (Ascochyta hordei), and Ramularia leaf spots (Ramularia collo-cygni). However, a comparison study showed that none of the above microbial leaf colonists were isolated from PLS (37), confirming an abiotic etiology of barley PLS as a kind of physiological disorder.

Nonparasitic spots have been reported by different authors in various plant species or organs under various names. Flor (14) described a nonparasitic disease of flax grown on calcareous soil as chlorotic dieback; a similar foliar necrosis in Chrysanthemum

Corresponding author: A. von Tiedemann; E-mail address: atiedem@gwdg.de

Publication no. P-2001-1217-01R

(C) 2002 The American Phytopathological Society spp. was also reported by Dienelt and Lawson and Lawson and Dienelt $(9,27)$. Smiley et al. $(42,43)$ used the terminology PLS to characterize a nonparasitic symptom of winter wheat in the northwestern United States.

In general, the etiology about these nonparasitic necrosis on various plants is not well understood. Various environmental or growth factors can cause necrosis of plants, such as light and temperature (7), growth status $(49,50)$, air pollution (21), herbicides (13), nutrient deficiency, or toxicity $(2,18,23,24)$. However, the primary causes and physiological and biochemical events underlying nonparasitic necrosis are unclear.

A further observation is that PLS in barley appear normally on the uppermost leaves and typical symptoms predominantly occur on the sites or parts of the leaf directly exposed to sunlight. Thus, it has been assumed that PLS are caused mainly by ultraviolet B radiation through the generation of toxic active oxygen species (AOS) (31). However, this assumption is still lacking clear evidence. In the present study, we scored the symptom development on 28 winter barley and 18 spring barley cultivars under field conditions in Rostock, northern Germany, for 2 years, with special attention on the AOS and the antioxidant capacity in leaves in relation to PLS formation and fungicide applications.

\section{MATERIALS AND METHODS}

Field sampling. Leaf spot scoring and leaf sampling were obtained in the cultivar evaluation experiment conducted by the State Experimental Station for Agriculture in Biestow, near Rostock, from 1999 to 2000. The experiment was arranged in a randomized block design with one plot $(1.5 \times 10 \mathrm{~m})$ per cultivar $\times$ fungicide combination and two replicates for each treatment. Growth stages (GS) were recorded following the decimal code (45). For winter barley, both years included treatments with fungi- 
cide and without fungicide, and for spring barley, the cultivar evaluation in 1999 included only fungicide-treated plots. Fungicide applications in winter and spring barley in both 1999 and 2000 seasons are listed in Table 1.

PLS symptom evaluation. In 1999, PLS incidence was scored four times from GS 39/45 (flag leaf stage) to GS 75 (medium milk), about once every 2 weeks in both spring and winter barley. In 2000, more intense evaluation on the incidence of PLS was made by scoring 11 times from GS 29 (end of tillering) to GS 75, once every 3 to 4 days in winter barley, and from GS 55 (ear emergence) to GS 75 , once every 4 to 7 days in spring barley. A disease rating scale of 1 to 9 was used to describe the symptom severity on the uppermost three leaves on main tillers with 1 indicating healthy and 9 indicating completely diseased. A specific scoring of the second leaves (F-1) was also made because they were used for biochemical analyses.

To identify potential biotic factors associated with PLS, F-1 leaves from severely affected cultivars with and without fungicide treatments were collected from the fields and sent to the Institute for Plant Protection of Field Crops and Grassland, Federal Biological Research Centre for Agriculture and Forestry (BBA, Kleinmachnow/Berlin). Affected leaves were incubated in moist culture dishes under UV light to encourage sporulation for direct microscopic identification of leaf pathogens, when appropriate.

Leaf sampling. Based on the PLS severity scoring in 2 years in the fields, winter barley cvs. Anoa, Sarah, and Bombay (susceptible) and Landi and Theresa (resistant), and spring barley cvs. Barke, Extract, and Chalice (susceptible) and Scarlett and Aspen (resistant) were selected for biochemical analyses. Leaves for enzyme analysis were snap-frozen in liquid nitrogen and stored at $-85^{\circ} \mathrm{C}$. All biochemical and histochemical analyses were conducted with the first leaves below the flag leaf $(\mathrm{F}-1)$ on the main tillers unless stated otherwise.

Measurement of superoxide anion $\left(\mathrm{O}_{2}^{-}\right)$and hydrogen peroxide $\left(\mathrm{H}_{2} \mathrm{O}_{2}\right)$. The superoxide anion assay was based on the

TABLE 1. Fungicide applications (liter per hectare) in winter and spring barley field experiments (Biestow, Rostock, NE Germany, 1999 to 2000) ${ }^{\mathrm{a}}$

\begin{tabular}{cll}
\hline Year & Winter barley & Spring barley \\
\hline 1999 & GS 32: 0.6 Juwel Top + 0.6 Harvesan & GS 32: 0.5 Harvesan \\
& GS 49: 0.6 Amistar + 0.6 Harvesan & GS 37: 0.8 Amistar \\
2000 & GS 32: 0.6 Juwel Top + 0.6 Harvesan & GS 32: 0.5 Harvesan \\
& GS 39: 0.4 Harvesan + 0.6 Pronto Plus & GS 37: 0.6 Amistar + \\
& GS 59: 0.6 Amistar + 0.6 Harvesan & 0.5 Pronto Plus \\
\hline
\end{tabular}

${ }^{a} \mathrm{GS}=$ growth stage (decimal code). Active ingredients of the fungicides contained per liter: Juwel Top, Kresoxim-methyl (125 g) + Epoxiconazole $(125 \mathrm{~g})+$ Fenpropimorph (150 g); Harvesan, Flusilazole (300 g) + Carbendazim (150 g); Amistar, Azoxystrobin (250 g); and Pronto Plus, Tebuconazole $(200 \mathrm{~g})+$ Spiroxamine $(375 \mathrm{~g})$. method of Elstner and Heupel (10) and further modified by Wang and Lou (48). The principle of the method is based on the detection of $\mathrm{O}_{2}^{-}$by oxidation of hydroxylamine, yielding nitrite which is measured by colorimetric reaction with sulphanilamide and naphthalene diamine yielding a red azo dye with an absorbance maximum at $540 \mathrm{~nm}$. Briefly, leaf disks (7-mm diameter) were submerged in $500 \mu \mathrm{l}$ of $50 \mathrm{mM}$ phosphate buffer ( $\mathrm{pH} 7.8$ ) containing $1 \mathrm{mM}$ hydroxylammonium chloride and incubated for $30 \mathrm{~min}$ at room temperature. Then $100 \mu \mathrm{l}$ of the incubation mixture was transferred into 96 well microtiter plates, adding $100 \mu \mathrm{l}$ of $17 \mathrm{mM}$ sulphanilamide in $30 \%$ acetic acid and $100 \mu \mathrm{l}$ of $7 \mathrm{mM}$ naphthalene diamine dihydrochloride and incubated for $20 \mathrm{~min}$ at room temperature. The absorbance was measured at $540 \mathrm{~nm}$. Calibration curves were established from 0 to $100 \mu \mathrm{M} \mathrm{NO}_{2}^{-}$. From the following reaction, $2 \mathrm{O}_{2}^{-}+\mathrm{H}^{+}+\mathrm{NH}_{2} \mathrm{OH} \rightarrow \mathrm{H}_{2} \mathrm{O}_{2}+\mathrm{H}_{2} \mathrm{O}+\mathrm{NO}_{2}^{-}$, the concentration of $\mathrm{O}_{2}^{-}$was calculated according to $\left[\mathrm{O}_{2}^{-}\right]=$ $2\left[\mathrm{NO}_{2}^{-}\right](\mu \mathrm{M})$ from the calibration curve. To verify that $\mathrm{NO}_{2}^{-}$production was due to $\mathrm{O}_{2}^{-}$generated by the leaf disks, a control containing superoxide dismutase (SOD) at $100 \mu \mathrm{g} \mathrm{ml}^{-1}$ or a reaction mixture without hydroxylamine was used.

The hydrogen peroxide assay followed the modified method of von Tiedemann (46). Leaf disks (7-mm diameter) were submerged in $500 \mu$ of reagent mixture containing $0.05 \%$ guaiacol and horse-

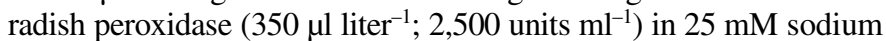
phosphate buffer $\left(\mathrm{pH} \mathrm{7.0)}\right.$ and incubated for $2 \mathrm{~h}$ at $20^{\circ} \mathrm{C}$ in the dark. A volume of $250 \mu \mathrm{l}$ was transferred into 96 well microtiter plates and the absorbance was immediately measured at $450 \mathrm{~nm}$ in a plate reader photometer (SLT Spectra, Germany).

Enzyme analyses. For enzyme extracts, $0.1 \mathrm{~g}$ of leaf tissue was ground with $2 \mathrm{ml}$ of precooled $50 \mathrm{mM}$ Na-phosphate buffer $(\mathrm{pH}$ 7.8), $0.1 \mathrm{mM}$ EDTA, and $1 \%$ (wt/wt) polyvinylpyrrolidone (PVPP). The extracts were centrifuged at $19,000 \times g$ for $20 \mathrm{~min}$ at $4^{\circ} \mathrm{C}$. Soluble proteins were assayed with Coomassie Plus Protein Assay Reagent (Pierce, Rockford, IL) by the method of Bradford (5) according to the manufacturer's protocol and using bovine serum albumin as a standard.

Peroxidase (POX) was assayed following the modified method of von Tiedemann (46). The reagent mixture was the same as for $\mathrm{H}_{2} \mathrm{O}_{2}$ measurement, except for POX being replaced by $10 \mathrm{mM}$ $\mathrm{H}_{2} \mathrm{O}_{2}$. Leaf disks (7-mm diameter) were submerged in 1,000 $\mu \mathrm{l}$ of reagent mixture in 24 well plates and incubated for $15 \mathrm{~min}$ at room temperature in the dark. A total of $250 \mu \mathrm{l}$ of reaction mixture was transferred into a 96 well microtiter plates. The absorbance of the brown guaiacol reaction was immediately measured at $450 \mathrm{~nm}$. POX activities were expressed as absorbance units (absorbance $\times$ 1,000).

Catalase activity (CAT) was assayed according to the description by Lyons et al. (29) from the decrease in absorbance at $240 \mathrm{~nm}$ following $\mathrm{H}_{2} \mathrm{O}_{2}$ consumption. The extinction coefficient used to calculate the activity was $39.4 \mathrm{mM}^{-1} \mathrm{~cm}^{-1}$ for $\mathrm{H}_{2} \mathrm{O}_{2}$ at $240 \mathrm{~nm}$.

TABLE 2. Incidence and severity of physiological leaf spot (PLS) in winter and spring barley cultivars treated (+FG) or untreated (-FG) with fungicides (Biestow, Rostock, NE Germany, 1999 to 2000$)^{\mathrm{a}}$

\begin{tabular}{|c|c|c|c|c|c|c|c|c|c|c|c|}
\hline & \multirow[b]{3}{*}{ Cultivar } & \multicolumn{4}{|c|}{ Winter barley } & & \multirow[b]{3}{*}{ Cultivar } & \multicolumn{4}{|c|}{ Spring barley } \\
\hline & & \multicolumn{2}{|c|}{1999} & \multicolumn{2}{|c|}{2000} & & & \multicolumn{2}{|c|}{1999} & \multicolumn{2}{|c|}{2000} \\
\hline & & $-\mathrm{FG}$ & $+\mathrm{FG}$ & $-\mathrm{FG}$ & $+\mathrm{FG}$ & & & $-\mathrm{FG}$ & $+\mathrm{FG}$ & $-\mathrm{FG}$ & $+\mathrm{FG}$ \\
\hline \multirow{5}{*}{ Sensitive } & Landi & 3 & 2 & 2 & 1 & & Scarlett & $\ldots$ & 1 & 1 & 1 \\
\hline & Theresa & 4 & 4 & 2 & $1-2$ & & Aspen & $\ldots$ & 3 & $2-3$ & 2 \\
\hline & & & & & & Sensitive & & & & & \\
\hline & Sarah & 4 & 3 & 4 & 2 & & Chalice & $\ldots$ & $\ldots$ & 5 & 4 \\
\hline & Anoa & 4 & 2 & 7 & $2-3$ & & Barke & $\ldots$ & $5-6$ & 6 & 3 \\
\hline
\end{tabular}

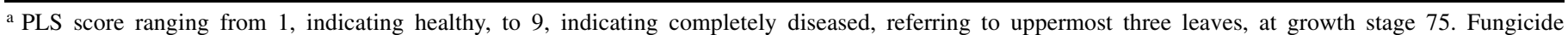
treatments are described in Table 1. 


\section{A}

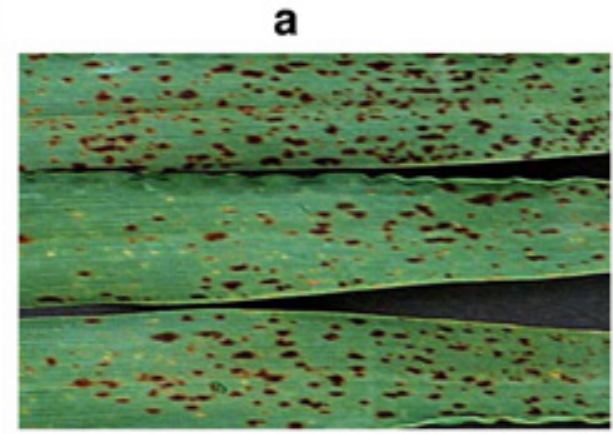

B

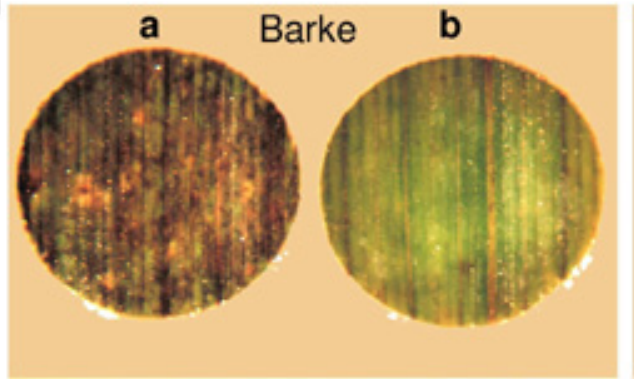

a

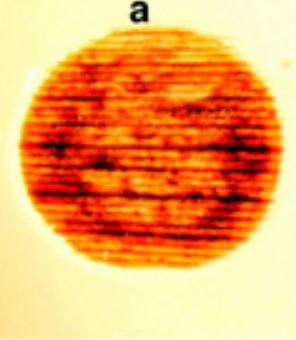

b

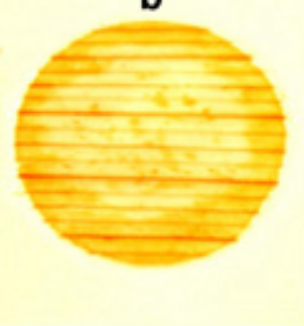

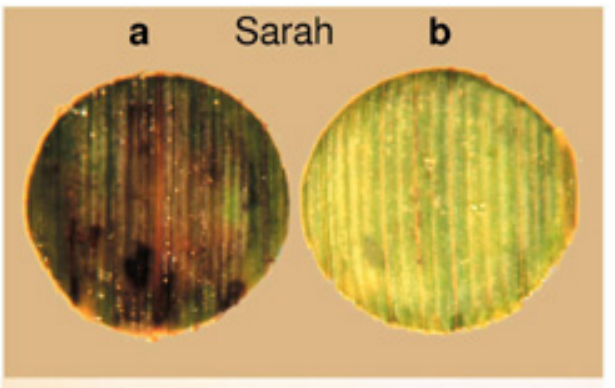

a

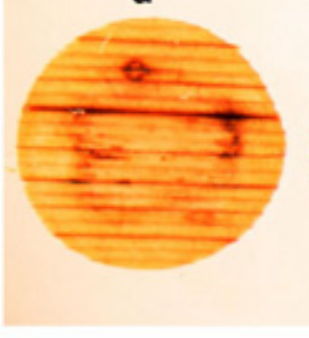

b

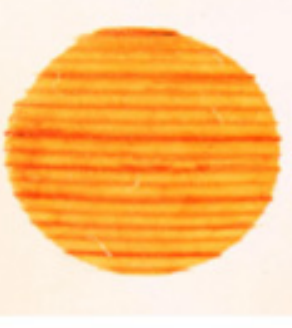

b

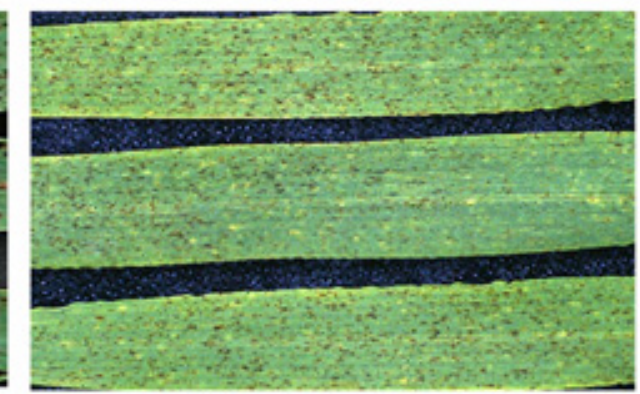

C
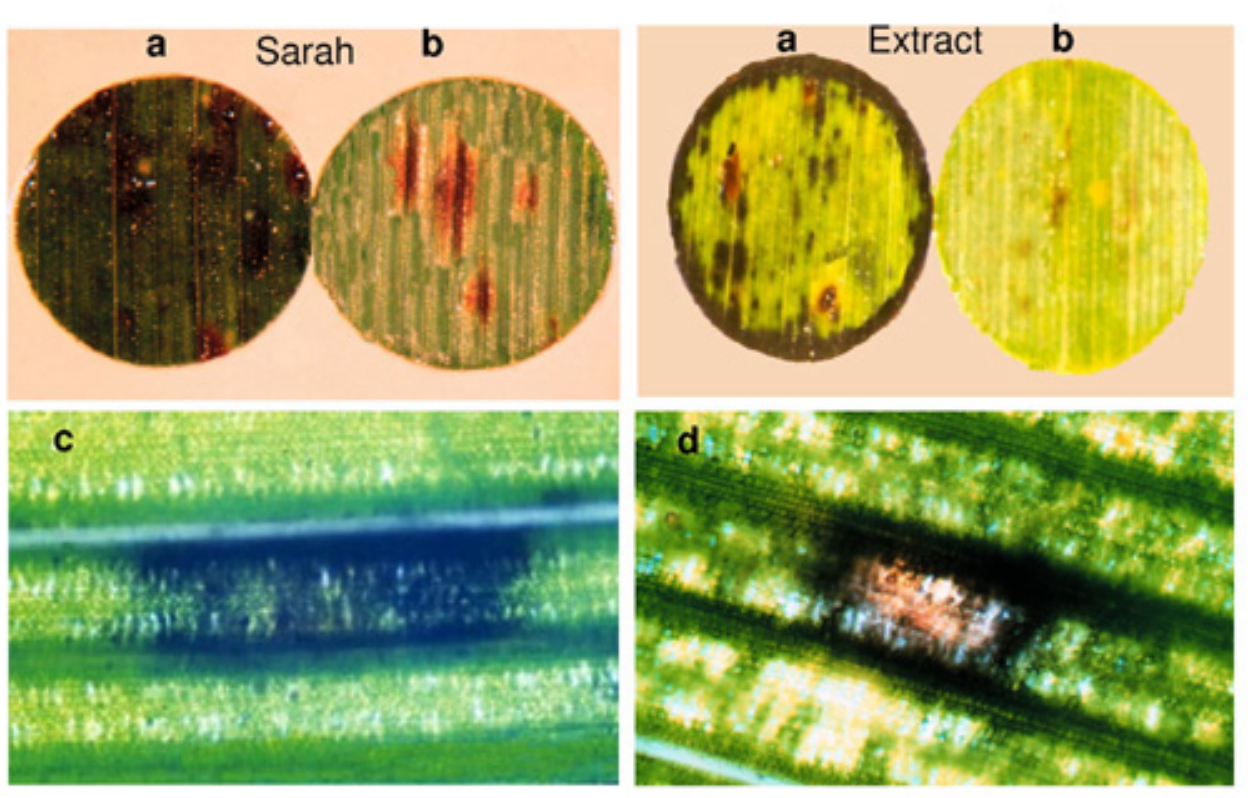

Fig. 1. Physiological leaf spots (PLS) in winter and spring barley and $\mathrm{H}_{2} \mathrm{O}_{2}, \mathrm{O}_{2}{ }^{-}$detection in situ. A, a: PLS symptoms on leaves of winter barley cv. Anoa; and b: PLS symptoms on leaves of spring barley cv. Barke with PLS generally smaller than those on winter barley. B, $\mathrm{H}_{2} \mathrm{O}_{2}$ accumulation visualized by benzidine Staining in leaf tissues (upper panel), stained leaf disks were cleared from pigments in a solution containing methanole/acetic acid (3:1, lower panels). B, a: Diseased leaf; and b: healthy leaf. C, $\mathrm{O}_{2}^{-}$production in leaf tissues with PLS symptoms detected by nitroblue tetrazolium chloride (NBT) staining in-situ. C, a: Leaf disks with NBT staining; b: leaf disks without NBT staining; c: stained cells at the initial stage of PLS formation (100×, cv. Sarah); and d: stained cells around PLS at an advanced symptom stage (100x, cv. Sarah). 
Total SOD activity was assayed according to the method of Elstner et al. (12) but modified by using xanthine/xanthine oxidase as $\mathrm{O}_{2}^{-}$generation system. The procedure and conditions of the assay were as follows: $1,000 \mu \mathrm{l}$ of incubation mixture consisted of $100 \mu \mathrm{l}$ of $0.6 \mathrm{mM}$ xanthine, $100 \mu \mathrm{l}$ of $10 \mathrm{mM}$ hydroxylamine, $100 \mu \mathrm{l}$ of xanthine oxidase (30 units/liter), $10 \mu \mathrm{l}$ of enzyme extracts, and $50 \mathrm{mM}$ phosphate buffer $(\mathrm{pH} \mathrm{7.8)}$. The mixture was incubated for $30 \mathrm{~min}$ at room temperature. An incubation mixture without enzyme extracts served as maximal absorbance control. The color reaction was the same as in the $\mathrm{O}_{2}^{-}$measurement.
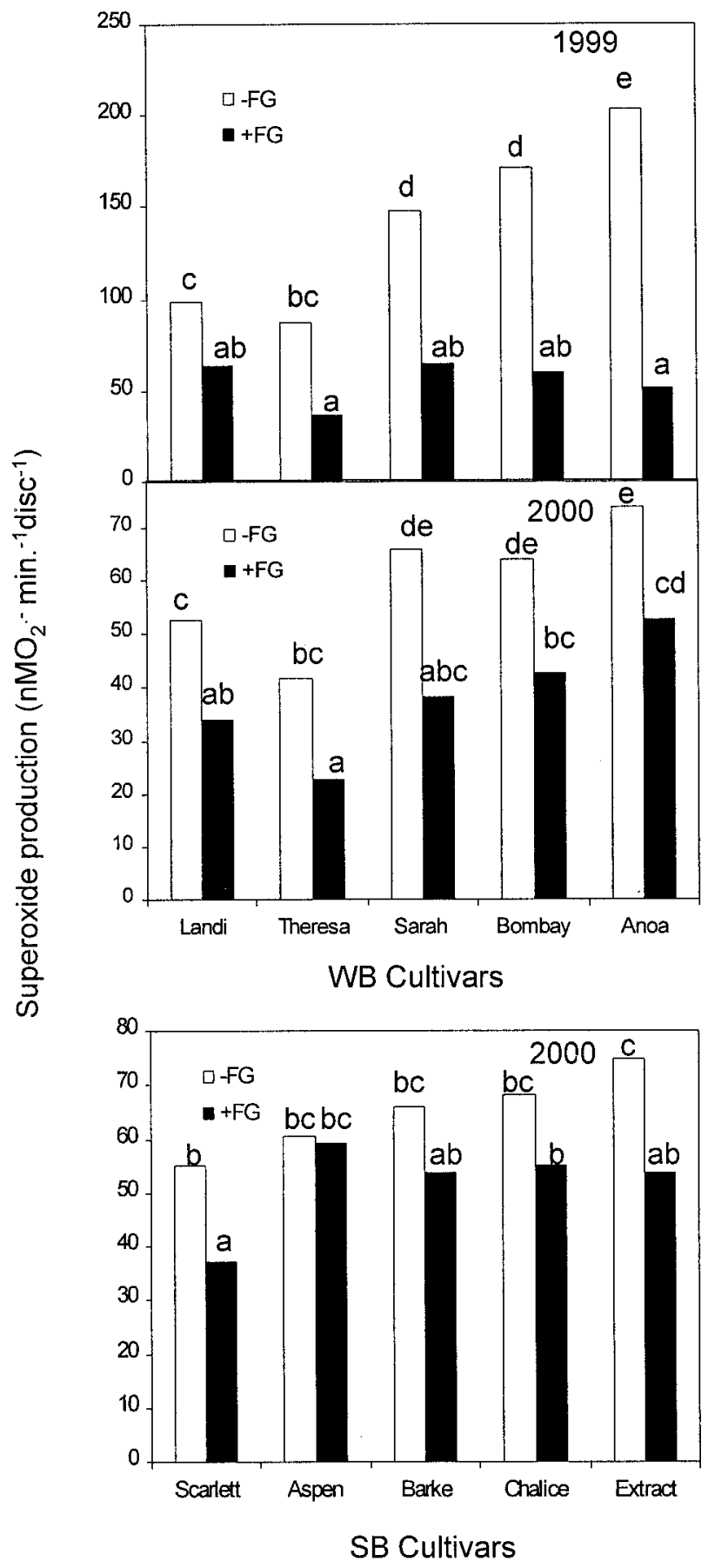

Fig. 2. Superoxide production of field-grown winter barley (WB) and spring barley (SB) genotypes with different sensitivity to physiological leaf spot. Sampled leaves were F-1 on main tillers at growth stage (GS) 49 (WB) or GS 55 (SB). Values are means of six replicates. Significant differences between cultivars and treatments are indicated on columns by different letters (least significant difference; $P<0.05$ ). Fungicide applications are described in Table 1.
One enzyme unit is defined as $50 \%$ inhibition of the colorimetric reaction.

Integral antioxidative capacity of water-soluble substances. The photo-induced chemiluminescence (PLC) method was performed on the Photochem analyzer (F.A.T., Analytic Jena AG, Jena, Germany) according to Popov and Lewin (34) with PLC assay kits (F.A.T., Analytic Jena). L-Ascorbic acid served as the calibration standard. The principle of the method is based on a suitable photosensitizer, which, upon excitation by UV irradiation, generates superoxide $\left(\mathrm{O}_{2}^{-}\right)$. Superoxide is detected with a chemiluminescent reagent. The chemiluminescence signal is affected by the presence of any antioxidants in the samples, which allows their quantification. Briefly, $5 \mu \mathrm{l}$ of appropriately diluted leaf extracts was added to the assay solution containing $1,000 \mu \mathrm{l}$ of carbonate buffer $(0.1 \mathrm{M}, \mathrm{pH} 10.5), 1,500 \mu \mathrm{l}$ of distilled water, and $25 \mu \mathrm{l}$ of luminol $(1 \mathrm{mM})$. Luminol played a dual role as photosensitizer and oxygen radical detection reagent. During the measurement, the solution was transferred into the measuring cell where chemiluminescence was determined. POPLAB 1.73 data acquisition software for Photochem (F.A.T., Analytic Jena) was used for all performances.

Lipid peroxidation. Lipid peroxidation was measured as the amount of malondialdehyde (MDA) determined by the thiobarbituric acid reaction described by Heath and Packer (20), with a small modification: $400 \mu \mathrm{l}$ of leaf extract (described previously) in $800 \mu \mathrm{l}$ of $0.5 \%$ thiobarbituric acid (in $15 \%$ trichloroacetic acid) was boiled for $20 \mathrm{~min}$ at $100^{\circ} \mathrm{C}$ and cooled in an ice bath. The reaction mixture was centrifuged for $5 \mathrm{~min}$ at $16,500 \times \mathrm{g}$. The supernatant was measured at $532 \mathrm{~nm}$, and an extinction coefficient of $155 \mathrm{mM}^{-1} \mathrm{~cm}^{-1}$ was used for calculation.

Histochemical localization of $\mathrm{O}_{2}^{-}$and $\mathrm{H}_{2} \mathrm{O}_{2}$. The method for $\mathrm{O}_{2}^{-}$detection was based on the procedure described by Ádám et al. (1). Leaf disks were vacuum infiltrated with a solution containing $300 \mu \mathrm{M}$ nitroblue tetrazolium (NBT), $10 \mathrm{mM} \mathrm{NaN}_{3}$, and $0.1 \mathrm{mM}$ EDTA. After $8 \mathrm{~h}$ of incubation, the disks were examined under the light microscope.

$\mathrm{H}_{2} \mathrm{O}_{2}$ accumulation in leaf tissue was detected according to the method of Thordal-Christensen et al. (44) but modified by using benzidine instead of 3,3'-diaminobenzidine. Leaf disks were vacuum infiltrated with $1 \mathrm{mg} \mathrm{ml}^{-1}$ benzidine solution, and $\mathrm{H}_{2} \mathrm{O}_{2}$ became visible as a strong reddish brown color at 8 to $12 \mathrm{~h}$ after infiltration. Finally, leaf disks were cleared of pigments in a solution with methanole/acetic acid (3:1) and examined under the light microscope.

Statistical analyses. All biochemical data were subjected to an analysis of variance to determine significant differences by least significant difference at the 5 and $1 \%$ level.

\section{RESULTS}

Incidence and severity of PLS on winter and spring barley and the impact of fungicides. The PLS disease on barley is characterized by necrotic spotting in the uppermost four leaves of sensitive cultivars. Initial symptoms are small chlorotic spots or small brown spots that may develop into larger necrotic lesions with irregular shape, with or without chlorotic halo (Fig. 1A). When the necrotic spots become visible in the lower leaves, upper leaves (younger leaves) are frequently affected by tiny chlorotic spots that are assumed to be the initial symptom of PLS. The size and shapes of PLS are variable among the sensitive cultivars and differ between winter and spring barley (Fig. 1A). In 1999 and 2000, PLS severity varied strongly among cultivars and ranged from 1 to 7 in winter barley and from 1 to 6 in spring barley (Table 2). Winter barley cvs. Rocca, Anoa, Sarah, and Bombay are highly sensitive cultivars as well as spring barley cvs. Barke, Gersau, Extract, and Chalice. Conversely, cvs. Landi, Theresa, Scarlett, and Aspen only slightly expressed PLS in both years in the field. However, PLS severity in some cultivars differed be- 
tween years, e.g., cv. Theresa was very healthy in 1999 until GS 69 (grade 1) (data not shown) and became severely affected at GS 75 , whereas in 2000 , symptoms of this cultivar were only slight. 'Anoa', the most sensitive winter barley cultivar, showed much more severe symptoms in 2000 than in 1999. These differences in PLS severity between years may be due to the specific environmental conditions in each year. PLS development was related to growth stage. The symptom expression was most predominant from GS 37/39 (flag leaf ligule visible) to GS 59/65 (ear emergence completed/half anthesis). Unlike fungal leaf spots on barley, PLS developed much earlier before the rows close over (as early as GS 22/29), whereas fungal spots generally associated with high humidity develop most when the rows close in (later than GS 55/59). Based on this observation, we conducted most of the biochemical analyses before GS 55 to minimize the influences of fungal diseases on the AOS metabolism.

Fungicide application in general markedly reduced the severity of PLS. PLS reduction rate induced by fungicides achieved a level up to $50 \%$ in some sensitive cultivars of both winter and spring barley, such as Anoa, Bombay, Sarah, Extract, and Barke (Table 2).

Oxidative stress in leaves of winter and spring barley with PLS symptoms. Resistant winter barley cvs. Landi and Theresa showed significantly lower levels in $\mathrm{O}_{2}^{-}$production than sensitive cvs. Sarah, Bombay, and Anoa $(P<0.05)$ (Fig. 2). This effect consistently occurred in both years 1999 and 2000, with the most sensitive cv. Anoa showing the highest $\mathrm{O}_{2}^{-}$levels in both years. $\mathrm{O}_{2}^{-}$ production in resistant spring barley cultivars was lower than in sensitive cultivars, but differences were smaller than on winter barley, with a significant separation of mean $\mathrm{O}_{2}^{-}$production only between resistant cv. Scarlett and sensitive cv. Extract (Fig. 2). Furthermore, $\mathrm{O}_{2}^{-}$production of winter barley without fungicide treatments was much higher in 1999 than those in 2000 (Fig. 2); correspondingly, PLS symptom expression was more severe at sampling GS (GS 49) in 1999 (data not shown). This difference may be related to the specific environmental conditions in each year. However, winter barley with fungicide treatments, which expressed the same level of PLS in both years, showed a similar level of $\mathrm{O}_{2}^{-}$production at GS 49 in both years (Fig. 2). Thus, $\mathrm{O}_{2}^{-}$ production level was closely associated with PLS expression.

Fungicide applications significantly reduced $\mathrm{O}_{2}^{-}$levels in leaf tissues of all winter barley cultivars tested $(P<0.05)$ (Fig. 2), which was consistent with the reduction of PLS by fungicides (Table 2). However, fungicide applications showed smaller effects

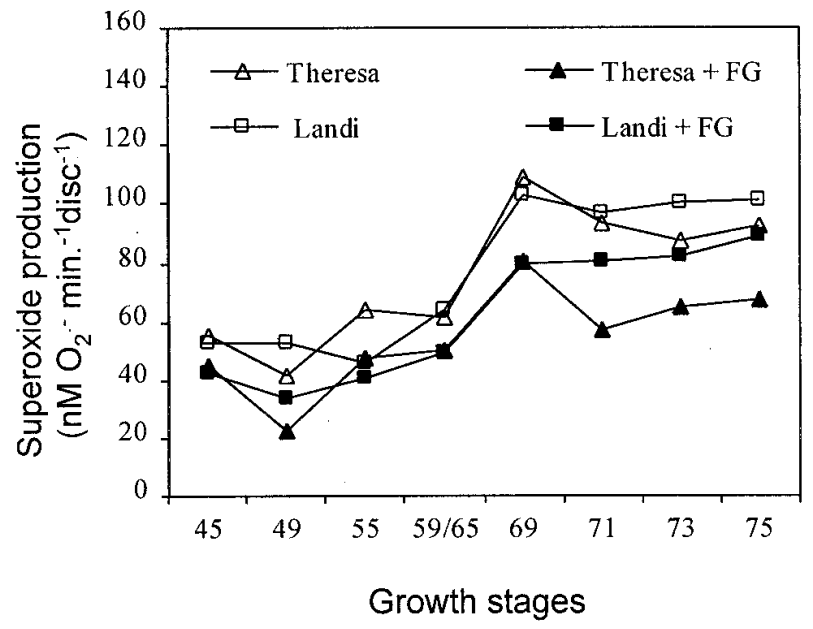

Fig. 4. Superoxide production in physiological leaf spot (PLS)-insensitive cultivars in the field in relation to growth stages and the impact of fungicide applications (+FG). Sampled leaves were F-1 on main tillers. Fungicide applications are described in Table 1. Values are means of six replicates (Biestow, Rostock, 2000).
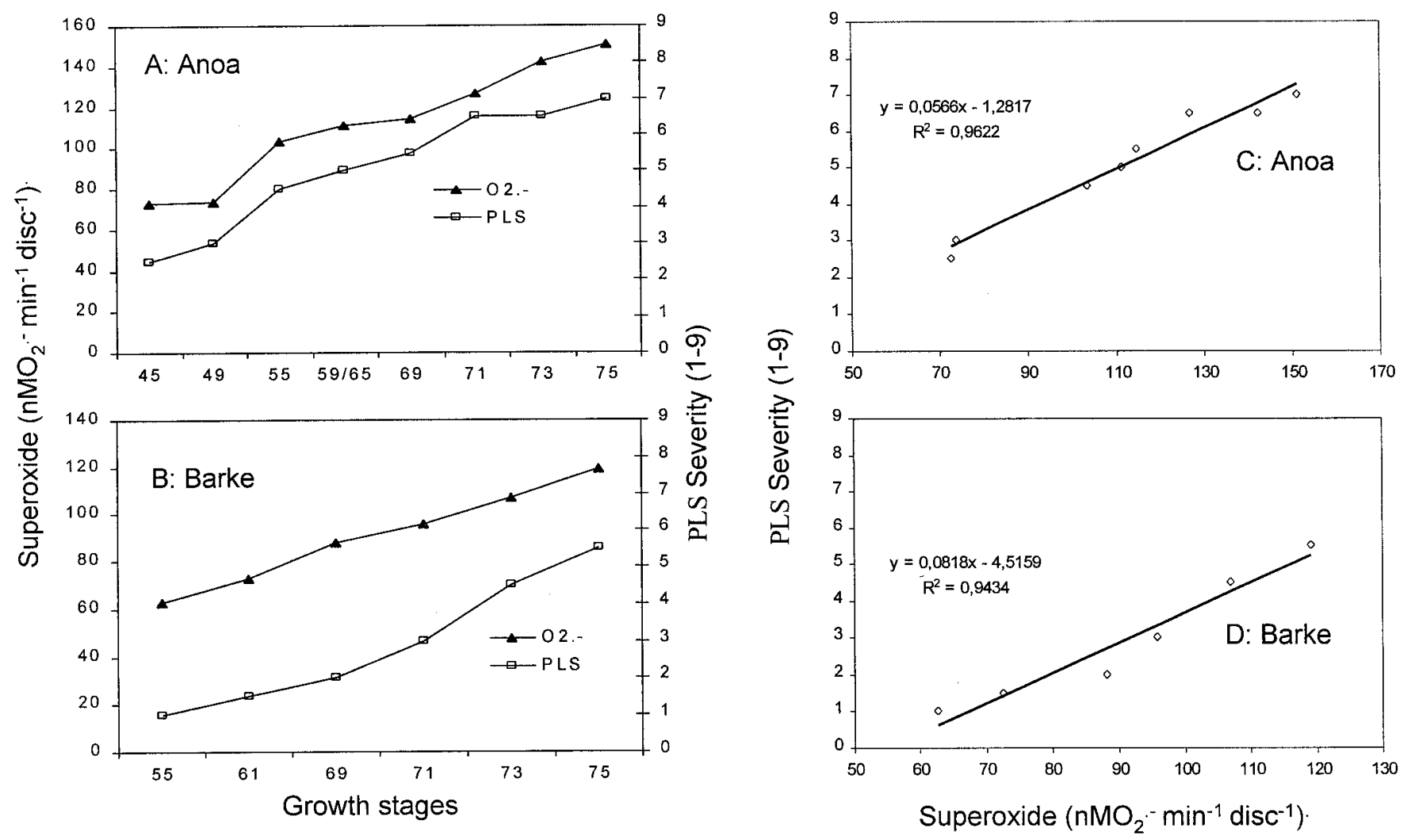

Fig. 3. Physiological leaf spot (PLS) development and superoxide production of field-grown winter and spring barley with growth stages (GS) and the correlation between PLS severity and superoxide levels in F-1 leaves on main tillers. Winter barley 'Anoa' sampled from GS 45 to GS 75 ( $n=8)$; and spring barley 'Barke' sampled from GS 55 to GS $75(n=6)$. Values are means of six replicates (Biestow, Rostock, 2000). 
on spring barley. This was probably because spring barley accepted less fungicide sprays (two times) or the last application at GS 37 was too early for effective protection (Table 1).

The $\mathrm{O}_{2}^{-}$level in leaf tissues of both winter and spring barley was closely correlated with PLS symptom development at increasing GS (Fig. 3A and B). A high positive correlation between $\mathrm{O}_{2}^{-}$production and PLS severity with advanced GS (from boots swollen to milk ripe) was established in cvs. Anoa and Barke (Fig. $3 \mathrm{C}$ and D). A positive correlation between PLS severity and $\mathrm{O}_{2}^{-}$ production was achieved in sensitive winter barley 'Sarah' $\left(r^{2}=\right.$ $0.6335)$ and spring barley 'Extract' $\left(r^{2}=0.763\right)$ (data not shown).

Compared with sensitive cultivars, $\mathrm{O}_{2}^{-}$production in resistant winter barley cvs. Theresa and Landi was only slightly increased during the critical GS for PLS symptom development (GS 45 to GS 59/65) (Fig. 4). However, $\mathrm{O}_{2}^{-}$production markedly increased at GS 69 (anthesis completed), indicating that plants turned to senescence and then declined ('Theresa') or maintained a constant level ('Landi') as the physiological functions declined with progressive senescence. Fungicides lowered the $\mathrm{O}_{2}^{-}$production throughout the GS investigated, especially at GS later than GS 69, which was in agreement with physiological effects of these fungicides leading to retardation of the ontogenetic senescence, known as the "greening effect" in the field. Accordingly, leaf senescence, indicated by percentage of nongreen leaf area, was significantly lower in fungicide-treated plants than in untreated plants (data not shown).
Another important AOS, $\mathrm{H}_{2} \mathrm{O}_{2}$, in leaf tissues of both winter and spring barley increased with the severity of PLS symptoms (Fig. 5). $\mathrm{H}_{2} \mathrm{O}_{2}$ content in leaves with severe PLS symptom grades (7 to 9) was significantly higher than in leaves slightly affected (1 to 3$)(P<0.05)$. There were no obvious differences in $\mathrm{H}_{2} \mathrm{O}_{2}$ content between fungicide treated and untreated leaves with the same symptom level, indicating that $\mathrm{H}_{2} \mathrm{O}_{2}$ depended mostly on PLS symptom severity.

Histochemical detection of $\mathrm{H}_{2} \mathrm{O}_{2}$ and $\mathrm{O}_{2}^{-}$in leaf tissues with PLS. To specifically localize the accumulation of the AOS adjacent to PLS, a direct in situ detection of $\mathrm{O}_{2}{ }^{-}$and $\mathrm{H}_{2} \mathrm{O}_{2}$ in leaves with or without PLS symptoms was performed. Benzidine is polymerized upon contact with $\mathrm{H}_{2} \mathrm{O}_{2}$ under preexisting POX in leaf tissues, producing a reddish brown color. Leaf tissues with PLS symptoms clearly showed strong benzidine staining, and even stronger staining was detected in the close vicinity of the PLS, indicating elevated levels of $\mathrm{H}_{2} \mathrm{O}_{2}$ in these tissues (Fig. 1B).

NBT is reduced by $\mathrm{O}_{2}^{-}$, resulting in formation of bluish diformazane, which remains in a bound insoluble state within the cell. Healthy cells were not stained by NBT although there were three types of NBT staining observed in diseased cells: entire spot stained (Fig. 1C, c), only cells around the spot stained (Fig. 1C, d), and no staining of the spots (data not shown), which reflected the three developmental phases of PLS: initial stage, developing stage, and final stage, respectively. At the initial and developing stages, cells around the PLS showed a strong staining, presumably
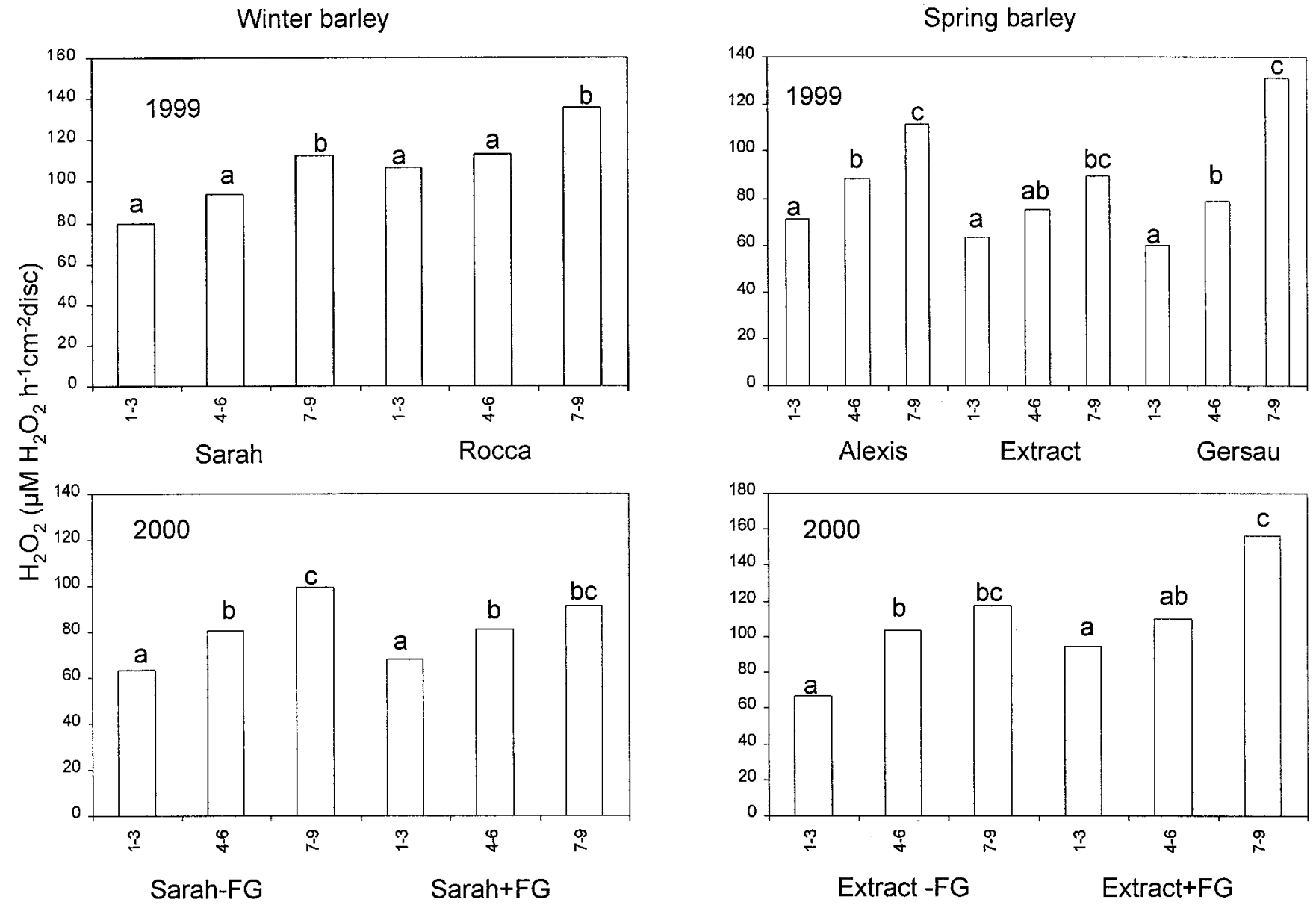

PLS symptom grade

Fig. 5. $\mathrm{H}_{2} \mathrm{O}_{2}$ content of winter and spring barley with different grades of physiological leaf spot (PLS) severity. Sampled leaves were F-1 on main tillers at growth stage (GS) 75. $-\mathrm{FG}=$ without fungicide treatments; $+\mathrm{FG}=$ with fungicide treatments. Fungicide applications are described in Table 1. Values represent means of three replicates. Significant differences of $\mathrm{H}_{2} \mathrm{O}_{2}$ content between symptom grades are indicated as different letters above the columns (least significant difference; $P<0.05)$. PLS score ranging from 1 , indicating healthy, to 9 , indicating completely diseased. 
because these cells were undergoing collapse due to high levels of $\mathrm{O}_{2}^{-}$. However, as the PLS completely formed, $\mathrm{O}_{2}{ }^{-}$was no more detectable because dead cells are unable to produce $\mathrm{O}_{2}^{-}$. Histochemical localization of $\mathrm{H}_{2} \mathrm{O}_{2}$ and $\mathrm{O}_{2}^{-}$in leaf tissues with PLS symptoms was in agreement with the biochemical detection.

Antioxidant status in leaf tissues of winter and spring barley with PLS symptoms. SOD activity in resistant winter barley cvs. Landi and Theresa was significantly higher than in the three sensitive cultivars in both 1999 and $2000(P<0.05)$ (Fig. 6). SOD activity in resistant spring barley cvs. Scarlett and Aspen was higher than in sensitive cvs. Barke, Chalice, and Extract, with significant differences between the two resistant cvs. Scarlett and Aspen and the two sensitive cvs. Chalice and Extract $(P<0.05)$ (Fig. 6).

Fungicide applications significantly increased SOD activity of winter barley in $1999(P<0.05)$, but the effects of fungicides on elevating SOD activity of winter and spring barley in 2000 was only significant on sensitive cultivars, except for Sarah $(P<0.05)$.

'Landi' and 'Theresa' showed significantly higher levels of CAT activity than the three sensitive cultivars of winter barley $(P<$ 0.05) (Fig. 7). CAT activity in resistant cultivars of spring barley was higher than in sensitive cultivars, however, statistically significant (5\% level) only for 'Chalice'. Fungicide applications generally elevated CAT activities of sensitive cultivars but suppressed it on resistant cultivars of both winter and spring barley.

In general, antioxidative capacity of water-soluble substances $(\mathrm{ACW})$ in resistant cultivars was significantly higher than in sensitive cultivars of both winter and spring barley, except for 'Scarlett' which showed a similar level in ACW as the sensitive cultivars. Fungicide application generally increased ACW levels in plants, particularly in spring barley while less pronounced in winter barley (Fig. 7).

Sensitive cultivars of winter barley showed significantly higher levels of POX activity than insensitive cultivars $(P<0.05)$ (Fig. $8)$. Fungicides decreased POX activity significantly in sensitive but not in insensitive cultivars. POX activity in sensitive cultivars treated with fungicides remained almost on the same level as insensitive cultivars, well in agreement with the PLS reduction by fungicides at GS 49 (data not shown). Furthermore, POX activity was increased with the severity of PLS symptoms in both winter and spring barley in 1999 and 2000 (Fig. 8), which corresponded with the $\mathrm{H}_{2} \mathrm{O}_{2}$ accumulation associated with PLS severity (Fig. 5).

Lipid peroxidation in leaf tissues of winter and spring barley with PLS symptoms. Lipid peroxidation, as characterized by MDA in resistant winter barley cultivars, was significantly lower than in the three sensitive cultivars $(P<0.05)$ (Fig. 9). MDA was also lower in resistant spring barley cvs. Scarlett and Aspen, however, lacking statistical significance. MDA content was increased with severity of PLS in both winter and spring barley. Fungicide treatments significantly decreased MDA in 'Anoa' and 'Bombay' $(P<0.05)$, with no statistical significance in the other cultivars of winter and spring barley.

\section{DISCUSSION}

PLS in barley and wheat are not caused by a microbial pathogen but by unknown genetic or yet undetermined abiotic factors $(6,15,42)$. However, in some regions in Germany and other European countries, Ramularia collo-cygni is often presumptively considered a contributor to the PLS complex, even though Ramularia collo-cygni has so far not been confirmed in the state of Mecklenburg-Vorpommern (NE Germany). Therefore, we assume that PLS incidence in winter and spring barley occurring in this region discloses the involvement of this fungus. The failure to isolate and identify any fungus from the spotted leaf tissues implied that nonparasitic disease on winter and spring barley, now commonly termed PLS, are due to a kind of physiological disorder. The fact that the incidence and severity of PLS varies with cultivars, seasons (Table 2), regions, and weather conditions (32) is in agreement with a report by Smiley et al. (42) on the PLS in winter wheat.

The causal mechanism of nonparasitic necrosis of plants is not as well understood compared with necrosis following a hypersensitive response (HR) caused by pathogens. Lummerzheim et al. (28) found some striking similarities between the HR induced by the phytopathogenic bacterium Xanthomonas campestris pv. campestris and necrotic lesions induced by lead on Arabidopsis plants on the macroscopical and microscopical level of expression of the lesions, and in the activation of defense responses, such as phytoalexin production, callose deposition, and the increase of stress-related enzymes. Thus, necrotic lesions caused by biotic and abiotic factors may share quite similar physiological mechanisms. AOS play a significant role in hypersensitive resistance responses of plants against pathogens $(1,25,35,46)$. AOS, such as $\mathrm{O}_{2}^{-}$and $\mathrm{H}_{2} \mathrm{O}_{2}$, are essentially involved in initiating lesion formation and programmed cell death $(22,33)$. The present data show that leaf tissues of winter and spring barley with PLS accumulated higher levels of $\mathrm{O}_{2}^{-}$and $\mathrm{H}_{2} \mathrm{O}_{2}$, and the accumulation of $\mathrm{O}_{2}^{-}$and $\mathrm{H}_{2} \mathrm{O}_{2}$ was correlated with the development and severity of PLS as well as with the genotypic difference in susceptibility to PLS in the field.
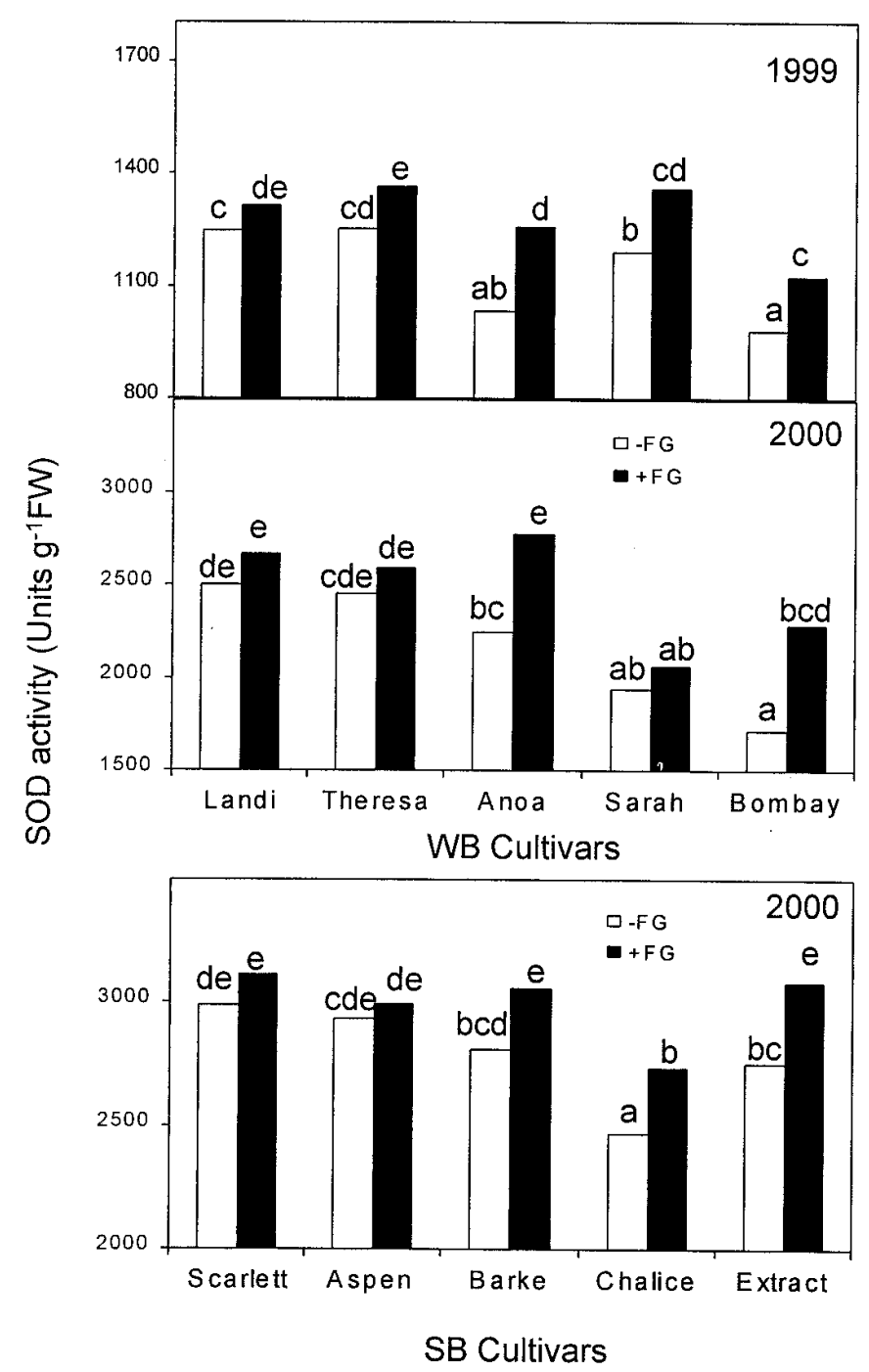

Fig. 6. Superoxide dismutase (SOD) activity of winter barley (WB) and spring barley (SB) genotypes with different sensitivity to physiological leaf spots. Sampled leaves were F-1 on main tillers at growth stage (GS) 49 (WB) and GS 55 (SB). Values are means of three replicates. Fungicide treatments $(+F G)$ are described in Table 1. Significant differences between cultivars and treatments are indicated as different letters above the columns (least significant difference; $P<0.05)$. 
This implies an important causal role for AOS in PLS formation. The direct localization of $\mathrm{O}_{2}^{-}$and $\mathrm{H}_{2} \mathrm{O}_{2}$ in cells adjacent to PLS further confirmed the causal involvement of AOS in the induction of PLS.

Because AOS are by-products of normal-working plant cells, aerobic organisms have evolved protective mechanisms or antioxidant defense systems, both enzymatic and nonenzymatic, to counteract the toxic and potentially lethal effects of AOS $(4,11$, 39). The present data support the assumption that the impaired or reduced AOS scavenging potential led to toxic accumulation of $\mathrm{O}_{2}^{-}$and $\mathrm{H}_{2} \mathrm{O}_{2}$ in leaf tissues with PLS, because susceptible cultivars possessed lower levels of antioxidant capacity such as SOD, CAT, and ACW than resistant ones. In general, the differences in total activities of SOD and CAT between resistant and sensitive cultivars were not as obvious as characterized by $\mathrm{O}_{2}^{-}$levels in leaf tissues, however, small changes in total enzyme activity may reflect much larger changes in enzyme activity in specific and critical subcellular compartments. This aspect, however, requires further detailed investigation.

POX activity, which can be induced by various environmental stresses (11), showed higher levels in susceptible cultivars and increased with the severity of PLS. An increasing POX activity may be a response to higher levels of $\mathrm{H}_{2} \mathrm{O}_{2}$ and be partially responsible for tissue browning in cooperation with phenoloxidase and lipid peroxidation products (11). An increased POX activity was associated with leaf necrosis induced by germanium in barley (19), or induced by X. campestris pv. campestris and lead in Arabidopsis (28).

Increased lipid peroxidation has been associated with apoptosis (38). Lipid peroxidation is commonly used as an indicator of oxidative stress (4) and can be initiated by various AOS during senescence, drought stress, ozone pollution, and HR resistance responses, leading to damage of membrane integrity $(3,25,32,40)$. Chlorosis and necrosis connected with lipid peroxidation are characteristic symptoms of oxidative plant damage induced by abiotic or biotic oxidative stresses (17). Dalal and Khanna-Chopra (8) found a close relationship between lipid peroxidation, membrane permeability, and cell viability in hybrid wheat leaves undergoing necrosis. A close relationship between AOS, lipid peroxidation, and necrosis induced by elicitins was found in Nicotiana spp. (36). Furthermore, lipid peroxidation products also contributed to cell necrotization (11). Thus, lipid peroxidation constitutes an early event in necrosis.

The present study shows that MDA, an end production of lipid peroxidation, was elevated in susceptible cultivars and in leaf tissues more severely affected by PLS, which was consistent with the accumulation of $\mathrm{O}_{2}^{-}$and $\mathrm{H}_{2} \mathrm{O}_{2}$, indicating that leaf tissues with PLS were undergoing detrimental oxidative stress.

In our study, application of azole and strobilurin fungicides strongly reduced PLS on both winter and spring barley. Smiley et al. (42) similarly reported that PLS on the F-2 leaves of winter wheat were reduced by the fungicides benomyl, mancozeb, and propiconazole. Applications of the growth retardant paclobutrazole induced $85 \%$ reduction of bud necrosis in grapevines (39). The necrosis reducing mode of action of these fungicides is not clear. Mackay et al. (30) and Senaratna et al. (41) reported that the triazole fungicides S-3307 and uniconazole protected tomato and wheat plants against ozone and chilling injury and were associated with an increase in the total lipid-soluble antioxidants and ascorbic acid levels. Our previous studies revealed that the strobilurin, azoxystrobin, and the triazole, epoxiconazole, exhibited strong

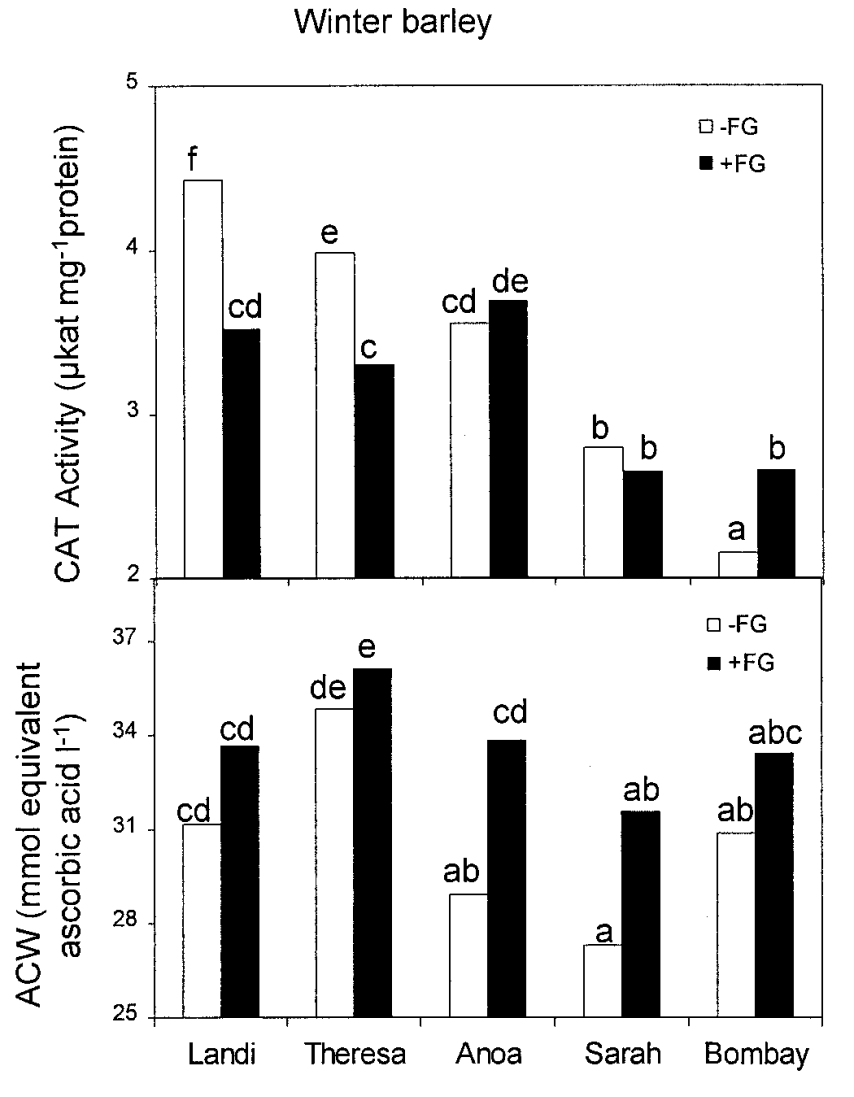

Cultivars

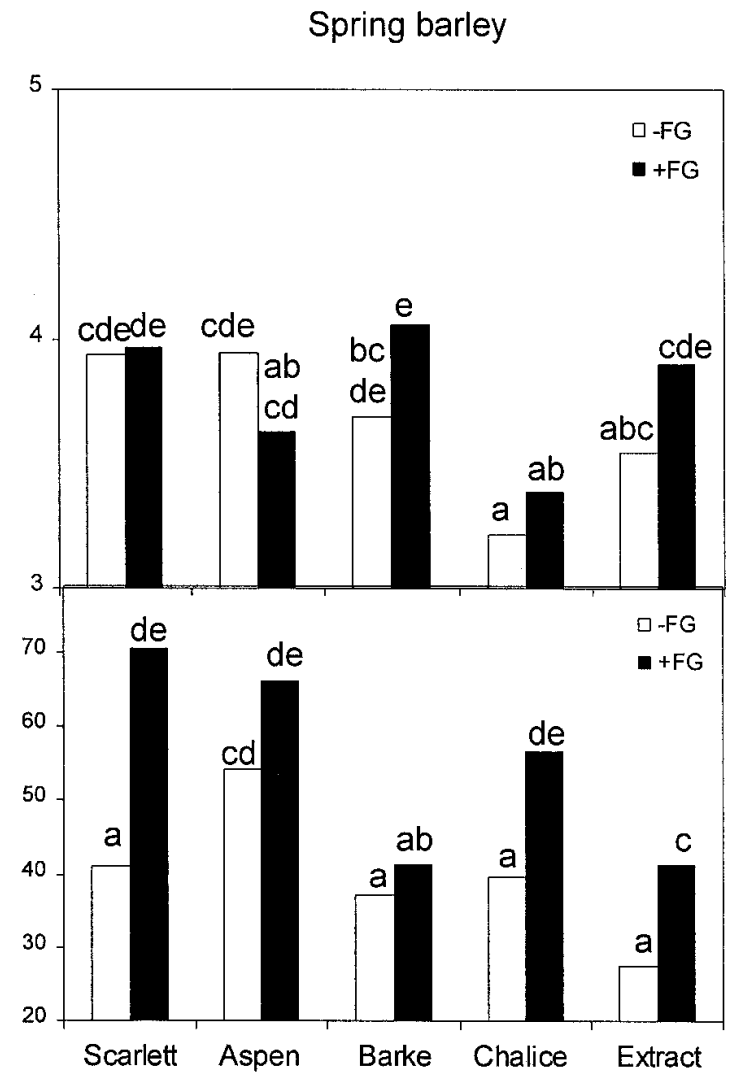

Cultivars

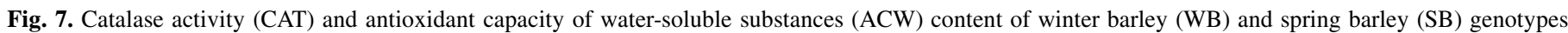

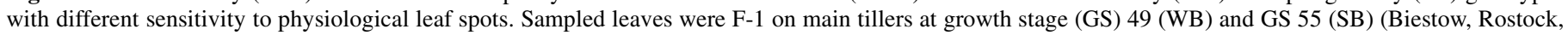

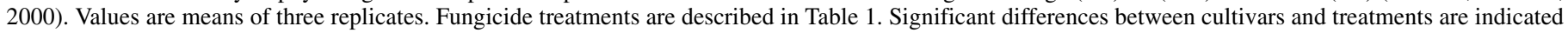
as different letters above the columns (least significant difference; $P<0.05$ ). 
antioxidative properties in delaying senescence and protecting barley and wheat from ozone injury $(50,51)$. The delayed-senescence effects by applying these fungicides related to suppression of $\mathrm{O}_{2}^{-}$ production was also found in the field conditions (Fig. 4). In the present study, PLS reduction by fungicides was always associated with elevated antioxidant potential, expressed as SOD activity and ACW content, and with suppressed $\mathrm{O}_{2}^{-}$production and lipid peroxidation, implying that fungicides may reduce PLS by increasing the antioxidant potential of plants. Nevertheless, the different responses of PLS and antioxidants to fungicide applications between winter and spring barley as well as between years imply that the effective protection by fungicides may be related to the total doses and classes of fungicides applied and the optimum GS of plants, which are to be further investigated.

The present results give a new line of evidence that PLS in barley are related to oxidative stress. However, it is not yet clear to what extent oxidative stress is a cause or consequence of this physiological disorder. The symptom expression in winter and spring barley is strongly related to the plant genotype (cultivars) and may be initiated by environmental stress events. During this study, it was also noted that sensitive cultivars grown in the greenhouse in the absence of pathogens developed symptoms similar to those observed in the fields. Sensitive and resistant cultivars of spring barley showed strongly different responses to various environmental stresses such as ozone, constant light and temperature stress, and light at different wavelengths (Y.-X. Wu and A. von Tiedemann, unpublished data). Therefore, specific unfavorable genotype-environment interaction may cause a specific physiological disorder on plants leading to PLS. Imbalance between the mechanisms triggering oxidative stress conditions and the cellular antioxidant defense systems may be an important component of this kind of physiologic dysfunction. From the present data, in general, AOS metabolism, as characterized by the level of SOD activity and $\mathrm{O}_{2}^{-}$production in both winter and spring barley, reflected the genotypic differences in sensitivity to PLS. Sensitive cultivars showed higher levels of $\mathrm{O}_{2}^{-}$production and lipid peroxidation and lower levels of SOD activity and ACW content than resistant cultivars. Recently, genes related to leaf spot $(l l s 1)$ in maize (18) and leaf necrosis (nec) in chickpea were identified (16). However, whether these genes are related to AOS metabolism is unclear. Abiotic lesions on $l s d 1$ (lesion simulating disease) mutant of Arabidopsis spp. are mediated by production of $\mathrm{O}_{2}^{-}$ (22). Khanna-Chopra et al. (26) reported a necrotic leaf lesion only occurring on F1 hybrids of wheat that exhibited a higher level of $\mathrm{O}_{2}^{-}$production than its parents, implying a genetic basis for elevated $\mathrm{O}_{2}^{-}$causing leaf necrosis. Thus, it is hypothesized that a possible genetic mechanism based on impaired AOS scavenging systems or enhanced AOS generation is induced by unfavorable environmental conditions and leads to PLS formation in sensitive winter and spring barley genotypes.

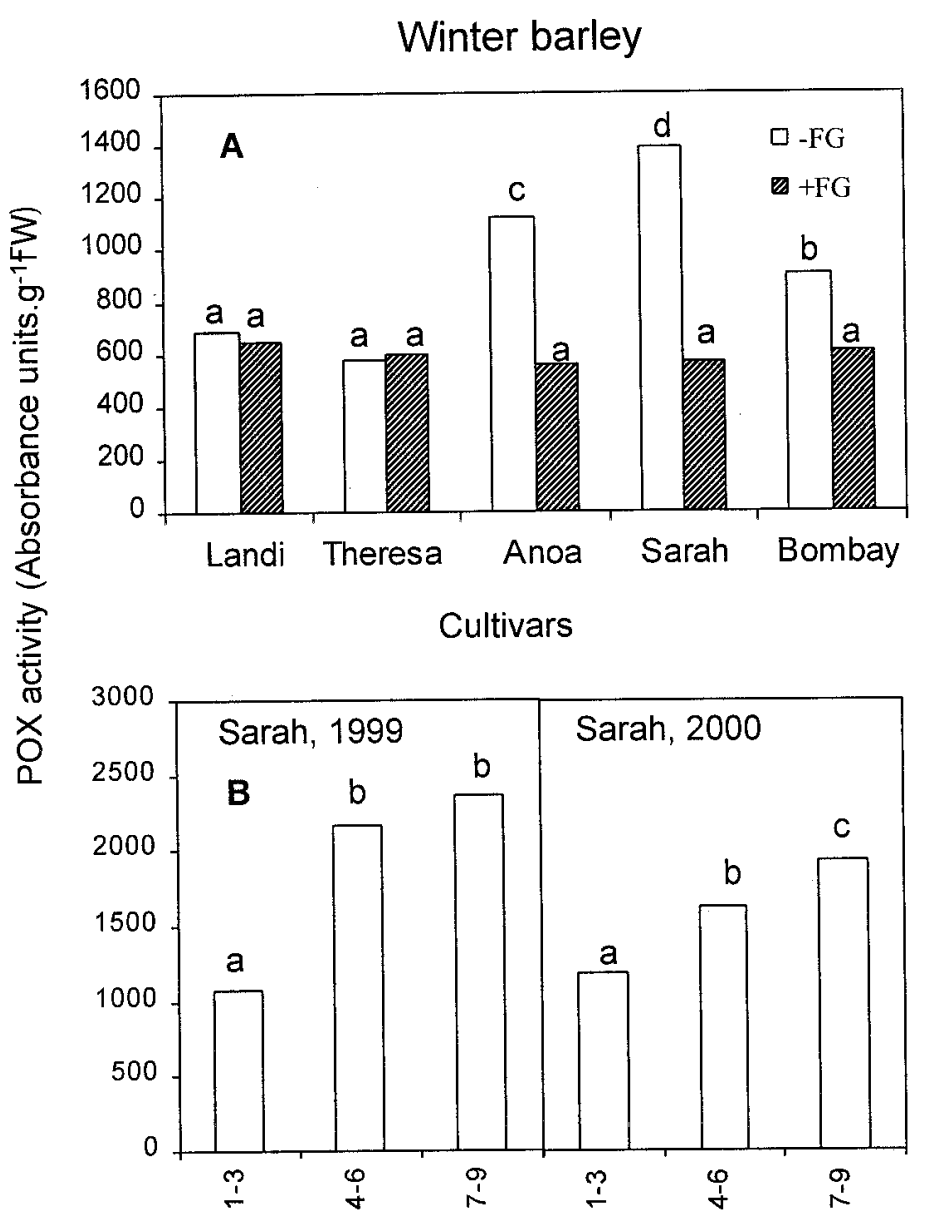

PLS symptom grade
Spring barley
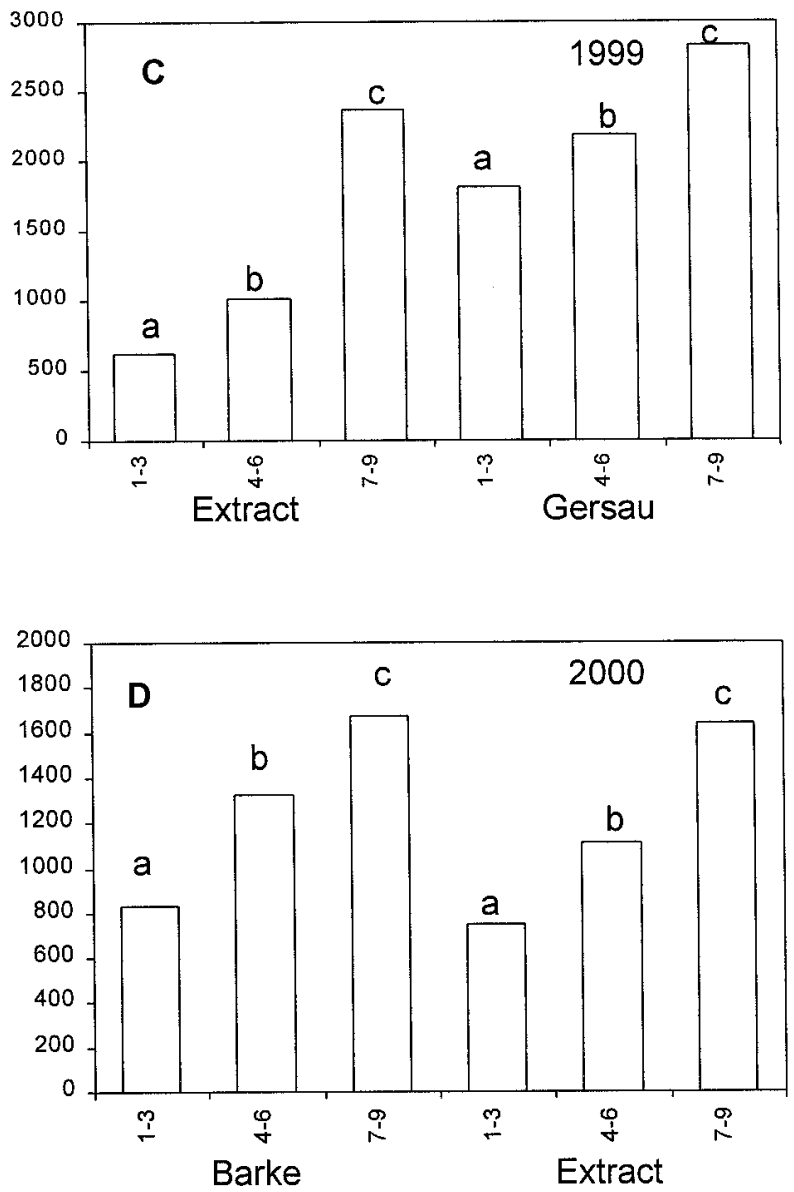

PLS symptom grade

Fig. 8. Peroxidase (POX) activity in leaf tissues of winter barley and spring barley. A, POX activity in winter barley with different sensitivity to physiological leaf spots (PLS). Sampled leaves were F-1 on main tillers at growth stage (GS) 49/51. B, C, and D, POX activity of winter and spring barley with different PLS symptom grades. Samples were F-1 leaves on main tillers at GS 75. PLS score ranging from 1, indicating healthy, to 9, indicating completely diseased. Fungicide applications are described in Table 1. Values are means of six replicates. Significant differences between A, cultivars, or B, C, and D, symptom grades are indicated by different letters above columns (least significant difference; $P<0.05$ ). 


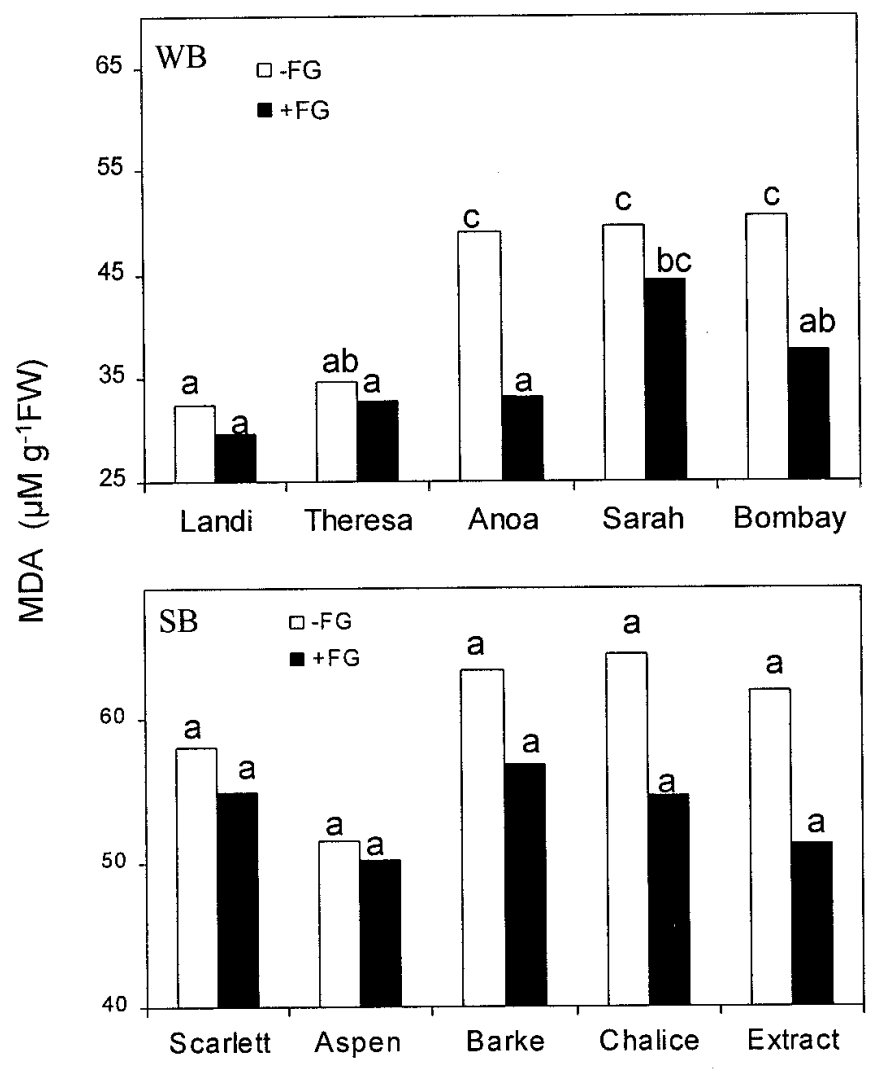

Cultivars
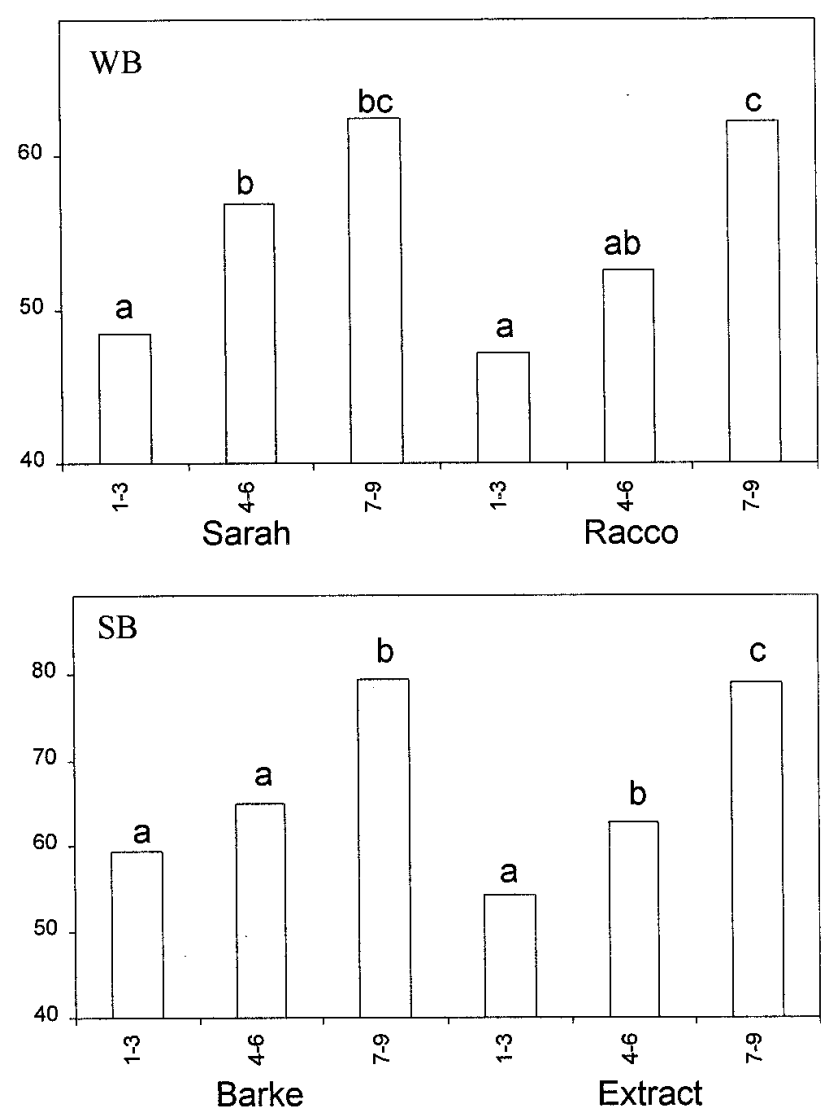

PLS symptom grade

Fig. 9. Lipid peroxidation (malondialdehyde) of winter barley (WB) and spring barley (SB) genotypes with different sensitivity to physiological leaf spots (PLS) and with different symptom grades. Sampled leaves were F-1 on main tillers. Cultivar evaluation was done at growth stage (GS) 49 (WB) and GS 55 (SB); symptom grade evaluation at GS 75. Values are means of three replicates. Significant differences between cultivars and symptom grades are indicated by different letters above columns (least significant difference; $P<0.05$ ).

\section{ACKNOWLEDGMENTS}

We thank the State Experimental Station for Agriculture of Mecklenburg-Vorpommern (Biestow, Rostock) for conducting the cultivar evaluation experiments, E. Sachs (Institute for Plant Protection of Field Crops and Grassland, BBA, Kleinmachnow, Berlin) for contributing diagnostic services, and ZENECA, Agro, which partly funded this study.

\section{LITERATURE CITED}

1. Ádám, A., Farkas, T., Somlyai, G., Hevesi, M., and Király, Z. 1989. Consequence of $\mathrm{O}_{2}^{-}$generation during a bacterially induced hypersensitive reaction in tobacco: Deterioration of membrane lipids. Physiol. Mol. Plant Pathol. 34:13-26.

2. Bachman, G. R., and Miller, W. B. 1995. Iron chelate inducible iron/ manganese toxicity in zonal geranium. J. Plant Nutr. 18:1917-1929.

3. Bailly, C., Benamar, A., Corbineau, F., and Come, D. 1998. Free radical scavenging as affected by accelerated aging and subsequent priming in sunflower seeds. Physiol. Plant Pathol. 104:646-652.

4. Bowler, C., Van Montagu, M., and Inzé, D. 1992. Superoxide dismutase and stress tolerance. Annu. Rev. Plant Physiol. Plant Mol. Biol. 43:83116.

5. Bradford, M. M. 1976. A rapid and sensitive method for the quantitation of microgram quantities of protein utilizing the principle of protein-dye binding. Anal. Biochem. 72:48-254.

6. Brown, W. M. 1996. Physiological brown spot widespread in Pacific Northwest also found in San Luis Valley and along front range. Colo. State Univ. Coop. Exten. Pest Alert Newsl. 13:3.

7. Cushman, K. E., Tibbitts, T. W., and Sharkey, T. D. 1995. Constant-light injury of potato: Temporal and spatial patterns of carbon dioxide assimilation, starch content, chloroplast integrity, and necrotic lesions. J. Am. Soc. Hortic. Sci. 120:1032-1040.

8. Dalal, M., and Khanna-Chopra, R. 1999. Lipid peroxidation is an early event in necrosis of wheat hybrid. Biochem. Biophys. Res. Commun. 262:109-112.

9. Dienelt, M. M., and Lawson, R. H. 1991. Chrysanthemum foliar necrosis: Transmission electron microscopy of leaf lesions. Phytopathology 81:1079-1087.

10. Elstner, E. F., and Heupel, A. 1976. Inhibition of nitrite formation from hydroxylammoniumchloride: A simple assay for superoxide dismutase. Anal. Biochem. 70:616-620.

11. Elstner, E. F., and Osswald, W. 1994. Mechanism of oxygen activation during plant stress. Proc. R. Soc. Edinb. Sect. B 102:131-154.

12. Elstner, E. F., Youngman, R. J., and Osswald, W. 1983. Superoxide dismutase. Pages 293-302 in: Methods of Enzymatic Analysis, Vol. 3. H. U. Bergmeyer, ed. Verlag Chemie, Weinheim.

13. Feierabend, J., and Winkelhüsener, T. 1982. Nature of photooxidative events in leaves treated with chlorosis-induced herbicides. Plant Physiol. 70:1277-1282.

14. Flor, H. H. 1943. Chlorotic dieback of flax grown on calcareous soils. J. Am. Soc. Agron. 35:259-270.

15. Fowler, D. B. 1997. Leaf spots. Pages 2201-2245 in: Winter Wheat Production Manual. D. B. Fowler, ed. CPS Conservation Production System, Saskatoon, Saskatchewan.

16. Gaur, P. M., and Gour, V. K. 2000. A gene for leaf necrosis in chickpea (Cicer arietinum $\mathrm{L}$ ). J. Hered. 91:79-81.

17. Goodman, B. A. 1994. The involvement of oxygen-derived free radicals in plant-pathogen interaction. Proc. R. Soc. Edinb. Sect. B 102: 479-493.

18. Gray, J., Close, P. S., Briggs, S. P., and Johal, G. S. 1997. A novel suppressor of cell death in plants encoded by the Lls1 gene of maize. Cell 89:25-31.

19. Halperin, S. J., Barzilay, A., Carson, M., Roberts, C., Komarneni, S., and Lynch, J. 1995. Germanium accumulation and toxicity in barley. J. Plant Nutr. 18:1417-1426

20. Heath, R. L., and Packer, L. 1968. Photoperoxidation in isolated chloroplast. I. Kinetics and stoichiometry of fatty acid peroxidation. 
Arch. Biochem. Biophys. 125:189-198.

21. Hill, A. C., Pack, M. R., Treshow, M., Downs, R. J., and Transtrum, L. G. 1961. Plant injury induced by ozone. Phytopathology 51:356-363.

22. Jabs, T., Dietrich, R. A., and Dangl, J. L. 1996. Initiation of runaway cell death in an Arabidopsis mutant by extracellular superoxide. Science 273:1853-1856.

23. Jackson, M. B., Lee, C. W., Schumacher, M. A., Duysen, M. E., Self, J. R., and Smith, R. C. 1995. Micronutrient toxicity in buffalograss. J. Plant Nutr. 18:1337-1349.

24. Jenelten, U., and Feller, U. 1992. Mineral nutrition of Arnica montana L. and Arnica chamissonis ssp. Foliosa Maguire: Differences in the cation acquisition. J. Plant Nutr. 15:2351-2361.

25. Keppler, L. D., and Novacky, A. 1987. The initiation of membrane lipid peroxidation during bacteria-induced hypersensitive reaction. Physiol. Mol. Plant Pathol. 30:233-245.

26. Khanna-Chopra, R., Dalal, M., Kumar, G. P., and Laloraya, M. 1998. A genetic system involving superoxide causes F1 necrosis in wheat $(T$. aestivum L.). Biochem. Biophys. Res. Commun. 248:712-715.

27. Lawson, R. H., and Dienelt, M. M. 1991. Chrysanthemum foliar necrosis: Symptoms, histochemistry, and X-ray analysis of leaf lesions. Phytopathology 81:1071-1078.

28. Lummerzheim, M., Sandroni, M., Castresana, C., de Oliveira, D., Van Montagu, M., Roby, D., and Timmerman, B. 1995. Comparative microscopic and enzymatic characterization of the leaf necrosis induced in Arabidopsis thaliana by lead nitrate and by Xanthomonas campestris pv. campestris after foliar spray. Plant Cell Environ. 18:499-509.

29. Lyons, T., Ollerenshaw, J. A., and Barnes, J. D. 1999. Impacts of ozone on Plantago major: Apoplastic and symplastic antioxidant status. New Phytol. 141:253-263.

30. Mackay, C. E., Senaratna, T., Mckersie, B. D., and Fletcher, R. A. 1987. Ozone induced injury to cellular membranes in Triticum aestivum L. and protection by the Triazole S-3370. Plant Cell Physiol. 28:1271-1278.

31. Obst, A., Baumer, M., and Huber, G. 1995. Leaf blotch of nonparasitic origin on barley-Does the damaging occurrence increase? Gesunde Pflanze 47:308-314.

32. Olsson, M. 1995. Alterations in lipid-composition, lipid-peroxidation and antioxidative protection during senescence in drought-stressed plants and non-drought stressed plants of Pisum sativum. Plant Physiol. Biochem. 33:547-553.

33. Panavas, T., and Rubinstein, B. 1998. Oxidative events during programmed cell death of daylily (Hemerocallis hybrid) petals. Plant Sci. 133:125-138.

34. Popov, I., and Lewin, G. 1999. Antioxidative homeostasis: Characterization by means of chemiluminescent technique. Pages 437-456 in: Methods in Enzymology: Oxidants and Antioxidants. Part B, Vol. 300. L. Packer, ed. Academic Press, San Diego.

35. Riedle-Bauer, M. 2000. Role of reactive oxygen species and antioxidant enzymes in systemic virus infections of plants. J. Phytopathol. 148:297302.
36. Rusterucci, C., Stallaert, V., Milat, M. L., Pugin, A., Ricci, P., and Blein, J. P. 1996. Relationship between active oxygen species, lipid peroxidation, necrosis, and phytoalexin production induced by elicitins in Nicotiana. Plant Physiol. 111:885-891.

37. Sachs, V. E., Amelung, D., and Klappach, K. 1998. The symptom of net blotch on barley, caused by Drechslera teres, and risks for diagnostic mistakes. Nachrbl. Dtsch. Pflanzenshutzd. 50:58-63.

38. Sandstrom, P. A., Pardi, D., Tebbey, P. W., Dudek, R. W., Terrian, D. M., Folks, T. M., and Buttke, T. M. 1995. Lipid hydroperoxide-induced apoptosis-lack of inhibition by bcl-2 over-expression. FEBS Lett. 365:66-70.

39. Scandalios, J. G. 1990. Response of plant antioxidant defense genes to environmental stress. Adv. Genet. 28:1-41.

40. Schraudner, M., Langebartels, C., and Sandermann, H. 1997. Changes in the biochemical status of plant cells induced by the environmental pollutant ozone. Physiol. Plant Pathol. 100:274-280.

41. Senaratna, T., Mackay, C. E., Mckersie, B. D., and Fletcher, R. A. 1988. Uniconazole-induced chilling tolerance in tomato and its relationship to antioxidant content. J. Plant Physiol. 133:56-61.

42. Smiley, R. W., Gillespie-Sasse, L.-M., Uddin, W., Collins, H. P., and Stroltz, M. A. 1993. Physiologic leaf spot of winter wheat. Plant Dis. 77:521-527.

43. Smiley, R. W., Uddin, W., Zwer, P. K., Wysocki, D. J., Ball, D. A., Chastain, T. G., and Rasmussen, P. E. 1993. Influence of crop management practices on physiologic leaf spot of winter wheat. Plant Dis. 77:803-810

44. Thordal-Christensen, H., Zhang, Z. G., Wie, Y. D., and Collinge, D. B. 1997. Subcellular localization of $\mathrm{H}_{2} \mathrm{O}_{2}$ in plant. $\mathrm{H}_{2} \mathrm{O}_{2}$ accumulation in papillae and hypersensitive response during the barley-powdery mildew interaction. Plant J. 11:1187-1194.

45. Tottman, D. R., and Broad, H. 1987. The decimal code for the growth stages of cereals, with illustration. Ann. Biol. 110:441-454.

46. von Tiedemann, A. 1997. Evidence for a primary role of active oxygen species in induction of host cell death during infection of bean leaves with Botrytis cinerea. Physiol. Mol. Plant Pathol. 50:151-166.

47. von Tiedemann, A., and Wu, Y. X. 2001. Sauerstoffstress in Blättern. DLG-Mitteilungen 2:40-42

48. Wang, A. G., and Lou, G. H. 1990. Quantitative relation between the reaction of hydroxylamine and superoxide anion radicals in plants. Plant Physiol. Commun. 6:55-57.

49. Wolf, T. K., and Warren, M. K. 1995. Shoot growth rate and density affect bud necrosis of 'Riesling' grapevines. J. Am. Soc. Hortic. Sci. 120:989-996.

50. Wu, Y. X., and von Tiedemann, A. 2001. Physiological effects of azoxystrobin and epoxiconazole on senescence and the oxidative status of wheat. Pestic. Biochem. Physiol. 71:1-10.

51. Wu, Y. X., and von Tiedemann, A. 2002. Impact of fungicides on active oxygen species and antioxidant enzymes in spring barley (Hordeum vulgare L.) exposed to ozone. Environ. Pollut. 116:37-47. 